\title{
RESEARCH NOTES
}

\section{Historical Memory And Cultural Immunity Of Society As Resources Of The Transformation Of The Culture Of Education}

\section{La Memoria Histórica Y La Inmunidad Cultural De La Sociedad Como Recursos De La Transformación De La Cultura De La Educación}

\author{
Konstantin V. Vodenko* \\ Doctor of Philosophical Sciences, Associated Professor, Professor, Department of Social and Humanity \\ Science, Platov South-Russian State Polytechnic University (NPI), Novocherkassk, Russia, \\ ORCID ID: 0000-0002-5283-0466

\section{Aleksandr V. Efimov} \\ Candidate of Economical Sciences, Associated Professor, Department of \\ Social and Humanity Science, Platov South-Russian State Polytechnic \\ University (NPI), Novocherkassk, Russia \\ ORCID ID: 0000-0003-3177-8045

\section{Oksana A. Bogdanova}

Doctor of Philosophical Sciences, Professor, Professor, Department of Philosophy and Cultural Studies,

Rostov State University of Economics, Rostov-on-Don, Russia.

ORCID ID: 0000-0003-3572-0537

Victoria V. Kotlyarova

Doctor of Philosophical Sciences, Associated Professor, Professor, Department of Social and Humanity Science, Institute of Service and Entrepreneurship (Branch), Don State Technical University, Shakhty, Russia

ORCID ID: 0000-0001-6419-6119

\section{Lyudmila A. Saenko}

Doctor of Pedagogic Sciences, Professor, Professor, Department of Social Technologies, North Caucasus Social Institute, Stavropol, Russia.

ORCID ID: 0000-0002-3423-4660

Received 09-08-20 Revised 10-10-20

Correspondencia

Email: vodenkok@mail.ru
Accepted 12-12-20 On line 03-15-21
Citar como:

Konstantin V. Vodenko., \& Aleksandr V. Efimov, Oksana A.
Bogdanova, Victoria V. Kotlyarova, Lyudmila A. Saenko (2021).
Historical Memory And Cultural Immunity Of Society As Resources
Of The Transformation Of The Culture Of Education. Propósitos y
Representaciones, 9 $\quad$ (SPE3), e1149.
http://dx.doi.org/10.20511/pyr2021.v9nSPE3.1149 Doi: 


\section{Summary}

This paper problematizes the current state of historical memory and cultural immunity as a cross-development trend in the field of education, noting that sociocultural thought has focused on understanding of historical memory and cultural immunity as parallel processes, and the transformation of the culture of education is described in relation to a new information reality, which gives rise to the dehistorization of the field of education. The author of the paper believes that the adoption of social and resource methodological schemes brings hope to get the answers for the two important aspects: first, cultural space of the educational society in the analysis of the effects of the wearable information technologies, and, in this regard, the degree of influence of historical memory and cultural immunity, second, the aspect that can be described as "specific" in the educational culture of Russian society, in which the "language" of globalization is translated into the culturehistorical context of national education.

Keywords: cultural immunity, culture of education, culture, education, actor, globalization, digital era.

\section{Resumen}

Este trabajo problematiza el estado actual de la memoria histórica y la inmunidad cultural como una tendencia de desarrollo transversal en el campo de la educación, señalando que el pensamiento sociocultural se ha centrado en la comprensión de la memoria histórica y la inmunidad cultural como procesos paralelos, y la transformación de la cultura de la educación. se describe en relación a una nueva realidad informativa, que da lugar a la deshistorización del campo de la educación. El autor del artículo cree que la adopción de esquemas metodológicos sociales y de recursos trae esperanza para obtener las respuestas para los dos aspectos importantes: primero, el espacio cultural de la sociedad educativa en el análisis de los efectos de las tecnologías de la información vestibles, y, en al respecto, el grado de influencia de la memoria histórica y la inmunidad cultural, segundo, el aspecto que se puede calificar de "específico" en la cultura educativa de la sociedad rusa, en la que el "lenguaje" de la globalización se traduce al contexto histórico-cultural de la educación nacional.

Palabras clave: inmunidad cultural, cultura de la educación, cultura, educación, actor, globalización, era digital.

\section{Introduction}

Every society, throughout its historical path of emergence and development forms social immunity, which, being a protection mechanism, allows regulating the impact of extraneous elements, blocking their adverse impact, effectively preserving stability and adaptivity of the internal social environment (Babloyan \& Vasilenko, 2018). Disfunctions of the immune system of society inevitably affect its state, being manifested in the growth of dysfunctional, destructive and disruptive processes at the level of institutional development and social interaction (Frolova, Aleshchanova \& Zheltukhina, 2019). Societies with compromised immunity are characterized by the deconsolidation trends, increase in conflictogenity in the field of interethnic, faith based, inter-generational and other relations, severe deficiencies in social trust, regressive or stagnant nature of economic development, crisis phenomena in the intellectual sphere, increase in crime, and decrease in social well-being (Shabalina et al., 2019; Vodenko, Borovaya \& Yefimov, 2020).

While we emphasize the significance of the above factors for the study of the stated problem, it should be emphasized that critical reflection is not unreasonable if it leads to the increase in the analytical, explanatory and forecasting potential of sociological thought, if social immunity of society is interpreted through the continuity of times, i.e. sociological knowledge, not pretending to fully reproduce the past, treats "the present" at the interface of the past and the future. Social immunity in this research context is defined by the indicators of social resistance to historical distortions. The perception of historical events and facts by means of "aggiornamento" or revision with a view to creating a "history of society" that would meet the interests of the general public.

Much of the above, if we draw on the data of All-Russian research and analytical solutions of sociologists, 
reflects the realia of modern Russian society (Russian society, 2018), hence, the issue of social immunity draws much attention of Russian scientists. Much work in this area has been done by sociologists (Zhapuev, 2013a; Zhapuev, 2013b) taking into account the sociological conceptualization of the range of problems of social immunity as such, development of methodological tools, and identification of common factors in functioning of the immune system of society as a social organism with a focus on institutional dynamics and specific nature of sociocultural development.

While we agree with this estimate, we have ground to claim the imperfection of the range of problems of social immunity as such, which records the social adaptation mechanisms and draws on the role sets of social groups and strata as the participants of the formation of historical memory, but can hardly analyze the behavioral aspect, which can be described as practices of historical memory of society compared to the degree of achieved social immunity. This complexity is emphasized by V.E. Boykov (2011), since his research interest is related to the era of cultural post-modernism, historical memory is affected by constructionism, and cultural immunity drops out of the field of research due to the definition of culture as determinants of social facts.

If we agree with the opinion of V.E. Boykov (2011) without doubt, we risk falling into a trap of culturological research that acts as a temporary replacement for the sociological analysis. As a matter of fact, that's not the issue: when we register changes in the sociocultural field of society under the influence of a new information reality, we need a conceptual clarification of culture and cultural immunity, as well as the influence of a new social reality on historical memory of society.

The significance of this factor lies in the fact that we are dealing with the phenomenon of the erosion of the image of classical culture, as well as with the fact that the information technology extends the limits of tolerance to phenomena that could otherwise be considered anti-cultural. If we monitor social networks, it becomes clear that there is a lack of criterion for the selection of cultural phenomena, and that the mechanisms of critical reflection of assessment of cultural changes taking place in public consciousness are unclear. This fact ambiguously gives rise to the new trends in the field of education, which is culture-shaping according to the classical model, but within the framework of a new information reality, first, is influenced by global standards, which is expressed in the phenomenon of glocalization and at the same time makes cultural immunity of society "regressive", which is treated as traditionalism directed against the progress as a result of successful globalism (Vodenko et al., 2020).

Second, cultural immunity is problematized within the framework of the transition to practice-oriented education, where there is a clear renunciation of the principle of cultural fundamentalism and the adoption of the competence criterion as a keynote of professional training of an expert with professional potential and the lack of adherence to cultural values and ideals. However, Russian society is not only clearly characterized by the preservation of cultural heritage, but also the generation of historical memory of society as a subjective resource for the formation of collective identity in the field of education.

This is reflected in the fact that according to the experience of the national sociological thought, Russian society is constructively oriented on the studies which are documenting the Russian specificity of new social realities (Gorshkov, 2016). Historical memory is associated not only with the preservation of the culture code of Russian society in an era of globalization, but also with the fact that the algorithms of public life, social myths, and invariant schemes of historical development are recorded in historical memory as a result of social "imagination" of society. It is obvious that historical memory becomes a resource for development of the field of culture in the context of historical education of society and the actualization of historical events and facts in correlation of trends of development of education with what we call the "historic vaccination" of the educational system.

However, from the perspective of social-philosophical reflection, the very mechanism of sociocultural development of society through the immersion into the world of culture, into culture as such as the source of social changes becomes fundamentally important; therefore, it is expedient to raise the question of cultural immunity of society, in which culture acts as "the means of physical, intelligent and psychological protection of an individual and society from external threats" (Kuts, 2015).

Changes that are taking place in the cultural life of Russian society are not only large-scale and unique from the perspective of the transition to a new information reality, but also dramatic (Shapinskaya, 2019). This dramatic nature is largely attributed to the problem of education, the crisis of which was marked not only by the destruction of the traditional educational system, which can be definitely expected in the light of dynamic changes in the social reality as such under the influence of global informatization and digitalization of the contemporary world, but also by several problems, which, taken together, are directly associated with the 
culture of education. Its paradigm transformation is interpreted by the scientists in a highly ambiguous manner in the context of the transition to the digital era, but it is obvious to us that changes in Russian culture of education most directly influence the cultural immunity of society.

Historical memory, being the basis in the development of collective identity, acts as one of cultural resources with a sufficiently high potential in terms of the formation of values and forms of social behavior. This gives us ground to turn to the study of resource of historical memory in the creation of a new social development model based on the synthesis of historic traditions and upgraded institutional structures, the implementation of which will help overcome crisis phenomena and ensure economic growth (Vodenko, 2020). The actualization of the historical memory problem is due to the need to understand further preservation of the culture code of people in an era of globalization, which serves to implement mainly liberal social development model to harmonize the cultural diversity of the world.

It seems that historical memory which contains experience of long-term peaceful coexistence of diverse ethnic groups within the framework of the Russian state, their efficient economic, political and cultural interaction may become one of the tools of consolidation of society on the civil basis. The potential of educational system for solving the problems of preserving, reproducing and passing on historical memory which is able to integrate society is manifested in the preservation of cultural heritage of the region through the educational system.

Within the scope of this paper, we formulate the problem which is related to the conceptualization and reflection of this obvious relation between the resource of historical memory and cultural immunity of society with the culture of education given the unclear and inconsistent results of this relation.

\section{Materials and Methodology}

In foreign research, historical memory is analyzed in the context of problems of "social memory" and "collective memory", described in the works of M. Halbwachs (2007) and P. Nora (1999); in the concept of "cultural memory" of Y. Assmann (2004); in Russian scientific discourse, the problem of historical memory is addressed by such authors as V.E. Boykov (2011), K.S. Romanova (2016), Z.T. Toshchenko et al. (2000). The researchers document the significance of historical memory in the conservation of the cultural traditions of peoples and provision of continuity of historic experience of generations. According to Z.T. Toshchenko (2000), historical memory is a "consciousness which has been focused in a certain way and is reflecting a particular significance and relevance of information about the past in close relation to the present and the future".

While we agree with this definition as containing analytical potential, we should introduce conceptual clarifications related to the implementation of the goal of research. It is clear that the sign of a somehow focused consciousness presented by Z.T. Toshchenko (2000) leads to the understanding of the social construct based on mechanisms of selection of historic evidences while correlating the social experience of society from the senary thinking with the willingness of society to shape the future images while understanding the links between the present and the past as the actualized historical heritage.

Thus, the conception of historical memory as a resource of development of education according to the resource diversity criterion and the conversion of the cultural and symbolic resource from the professional standpoint of the actor of educational system are taken as the basic principles of the research. More specifically, we may talk about the space of research discourse, which introduces the concepts of historical memory and cultural immunity of society, the culture of education on the principle of a hierarchical relationship in which the analytical components are the state of collective identity in the educational system, culture of historical memory, parameters of cultural immunity as the capability to resist historical directions, creating the effect of distortion of public consciousness, and finally, the logical sequence of assessment of consequences of informatization of education as such that contains contradictory tendencies (Bayanova et al., 2019; Vodenko et al., 2019; Vodenko et al., 2018).

It is obvious that achieving the research objective implies abandoning sociological unidimensionality and reliance on Russian and foreign studies of historical memory within the framework of the social and resource approach using the formula of "resource diversity" to track the logic of development of education at the level of conceptual self-limitation by the culture of education as an indicator of changes in behavioral practices of society.

This research is also based on the concept of cultural immunity, which from the perspective of the system approach proposed by Z.A. Zhapuev (2013a; 2013b) is one of constituent elements and definitely key elements of the immune system of society. Further, the research is based on the concept of N.L. Varova (2012) who 
claims that the culture of education combines two key elements of civilizational dynamics: development of a personality and the quality of knowledge.

As we can see, historical memory is presented in diverse aspects in the space of research discourse: as a social construct of the past defining the behavior models of people; as an institution which provides intergenerational continuity in the social medium; as a means of preserving cultural identity; as a political resource. These approaches seem to be fairly conceptual for the study of resource potential of historical memory in the development of the culture of education.

\section{Results}

Cultural immunity as the subject of scientific analysis and social-philosophical reflection in particular still represent a promising line of research, since it has thus far attracted attention of few scientists, in spite of the fact that there are many works revealing and foregrounding negative, sometimes catastrophic processes in the field of Russian culture started during the disintegration of the USSR and the subsequent reforming period. For example, S. Kara-Murza (2016) writes about this, pointing out that culture suffered a heavy blow during the Perestroika and subsequent reforms, and the mechanisms of destruction of culture which were launched in this period have entered the mode of self-reproduction and even self-acceleration; as a result, this process assumed proportions of a national disaster and "no program to block this process and restore the damaged parts has been developed either by the state or by society".

Other scientists analyze the dynamics of culture in Russian society from the perspective of the impact of external factors rather than internal factors, Identifying globalization as a key factor in sociocultural dynamics, and noting the complex dialectics of global sociocultural development, which could not but resulted in the crisis due to a number of reasons: first, due to the highest degree of integration of the cultural process into the socioeconomic system which caused the simplification of the cultural process, and second, due to the fact that the process of cultural segregation into "show business" and "true culture" has become a property classifier. As a result, a topical issue was raised on the agenda of how much the concept that is considered to be a culture even in the "industrial" sense (Yevstafiev \& Tsyganova, 2020) has preserved in the globalized world.

It is clear that all these and many other issues associated with the transition of culture in the era of digital technologies, rapid development of a new media-reality, massification of society etc., can and should be examined in the context of cultural immunity of society, which still cannot give answers to many questions at the level of scientific reflection, including with regard to the very concept of cultural immunity. The concept of social immunity is more elaborated within this framework.

Judging from the very essence of immunity as the system of protection and self-regulation of living organisms which it belongs to in line with the organic sociological tradition, social immunity is described as "the resilience of society to social risks and threats, primarily external ones, associated with the penetration of extraneous elements (values, norms, and cultural patterns) into the social organism, which destroy its integrity, integratedness, and adaptive potential" (Zhapuev, 2013a; Zhapuev, 2013b).

However, according to the author of this definition Z.A. Zhapuev (Zhapuev, 2013a; Zhapuev, 2013b), the abovementioned resilience of society to risks and threats implies the presence of the immune system as the protection mechanism of society, which, being sensitive to extraneous elements penetrating into social and cultural fabric of society, is responsible for regulating the level of risks and threats, thus preserving the high adaptability of internal environment and the sustainability of the sociocultural basis (Zhapuev, 2013a; Zhapuev, 2013b).

Within the framework of the implementation of the goals of the research, it is necessary to mention that cultural immunity as an idea that reflects the concept of risk society may be to some extent extraneous for the analysis of historical memory as a resource for the transformation of social culture, if we disregard the lack of definition for the criteria of "invasion" into the cultural fabric of society, which result in the lack of transformation of culture in the situation of half-decay and decay of the culture code of society. Within this framework, the demand for historical memory in Russian society is defined both by historic experience of generations and by the utilization of historical memory in an effort to assess social well-being at the present time (Gorshkov, 2016)

In this regard, it seems expedient to present sociological information about the influence of culture-historical and social context on distinctions in the assessment and perception of historical memory as a resource for the development of the culture of education and education in general, as well as overcoming the "digital conception" of paths of development of sociocultural space. It should also be emphasized that Russian society has gone through the period of digital euphoria of association of the culture of education with information 
technologies, and the awareness of the problem of complementarity of cultural heritage (fundamental principles of education, academism) with the improvement of mechanisms of self-regulation of education for the formation of efficient educational policy in conjunction with the development of social cognition and rationality of interrelationship of education actors emerges full blown.

Cultural immunity, from the perspective of the system approach proposed by Z.A. Zhapuev (Zhapuev, 2013a; Zhapuev, 2013b), is one of constituent elements and definitely key elements of the immune system of society. However, according to V. Kuts (2013), one of a few researchers who has addressed the issue of the category of cultural immunity at the level of philosophic and culturological reflection, its peculiarity lies in the fact that this immunity functions instinctively and it is virtually impossible to consciously control it. On the other hand, cultural immunity as such, according to this author, is "the system of self-regulation of information systems, the protection system in a culture which must protect our own intelligence and social culture from the destabilizing influence of other cultures. Moreover, this protection that functions based on self-regulation, must be inconspicuous, almost subconscious" (Kuts, 2013).

It should be pointed out that the organic direction has its own history of development in Russian social and philosophic thought, which is often associated with the name of P. Lilienfeld (Actual problems of social cognition, 1982), who has expressed his ideas and views as far back as in his work "The Land and the Freedom", which went out as early as in 1868 . He used it to justify the paramount importance of spiritual potential in the development of society, the cultural level of the people and an individual from the perspective of organic theory, and to draw conclusion on the key role of education in shaping the culture of the people, its cultural abilities. According to him, education must nurture spiritual qualities in a person based on the idea of a Higher Being (Kuzmina, 2010). The sociocultural realia of the time defined religious and moral principles as the most important spiritual foundations, but the very idea of the spiritual education of an individual, without taking into account its grounds (religious, secular), is as relevant as ever even today, when digital thinking threatens to actually push the human essence out of human nature and society.

According to P. Lilienfeld (Actual problems of social cognition, 1982), the education as such must aim for improvement, guided by ethical principles, which is directly associated with the culture of education which will be further discussed in our article.

\section{Discussion}

We have already mentioned that the field of culture has fallen into a trap due to the fact that culture has become embedded in the economic system, gradually dissolving its boundaries and losing its essential purpose and itself in the segregation between show business and culture, and in this regard, we should turn to the educational system, which serves as the basis for the cultural reproduction of society and its cultural immunity.

The education must provide more than the skills to adapt to modern labor market conditions, economic realia and changes. Education must build a holistic picture of the social life and place of the human being in the social world, in which an individual will have to build his own present and future, harmonizing it with individual and community values and needs. And these thoughts are embodied in the works of philosophers who turned their academic interest to the problem of the culture of education. Thus, N.L. Varova (2012), claims that the culture of education combines two key elements of civilizational dynamics: development of a personality and the quality of knowledge. Moreover, the latter should be oriented towards the formation of common meanings and goals in society, and together the two identified objectives must ensure the formation of such most important characteristic of human existence as knowledge of one's own presence in the world, which implies, in turn, knowledge of the world.

Education is thus responsible for giving the students a holistic view of the world they live in, and common senses; however, modern education does not fulfil this function, as it fails to cope with rapid changes, trends of rapid obsolescence of experience, technologies, and knowledge; as a result, the principles of continuity between the past and the future, between generations with their existential experience and meanings of life, between social institutions of education and labor) are violated.

Why is this happening? We believe that the main problem lies in the fact that the culture of education itself as the substance of the entire educational system of society is currently in a turbulent condition; it is going through a period of transformation, which is expressed in its crisis and destruction of traditional functions; therefore, the educational system which is aimed at setting the spirit of times, to act as the trumpet of the era, has dramatically changed its course, having become driven by market and economic trends, requests and needs.

Of course, we cannot ignore the trends of the modern era and the transition to information (digital, electronic) technologies which have already become dominant and unavoidable in a modern social reality, including 
educational reality, as the coronavirus pandemic has demonstrated to us (Lubskiy \& Kovalev, 2020); however, the logical question arises: what will happen to culture in general and the culture of education in particular in the future which can no longer be imagined without digital communicative technologies? Maybe they will change the very essence of culture, and maybe culture within its meaning as a "behavioral program to ensure the collective nature of people's lives" (Flier, 2017) in a new sociality of a virtual nature, which is already able to replace the real social space of interaction? Can virtual community as a community formed in the Internet become the basis of real behavioral practices that create the cultural foundation of society, its meaning and value constants which are required for the sociocultural reproduction of society as societal integrity? Wouldn't that be a simulacrum? Maybe the educational system will become a complete simulacrum following the transition to digital (online, remote) mode of operation? Wouldn't we lose the actor (educational, scientific, labor, etc.) in the format of such an approach to education, when its very essence, being subject to the trends of a market society, is lost? Moreover, this essence involves the transmission of cultural norms and values in the historical and civilizational plane of society.

In this context, our thoughts overlap with the opinion of Y. Agapov (2013), who absolutely justifiably links the processes of formation of an actor in an activity to the mechanisms of cultural inheritance in the educational and pedagogic environment, in communication and interaction, in the course of a normal daily living together, and raises a topical question - what should be the mechanisms for forming a full-fledged (educational, pedagogic) actor in this day and age? Or can it be formed when there is a global process of simplifying communication due to the adoption of digital technologies, acceleration of the communication process as such, and acceleration of data transmission due to the same reason (Zhuk, 2018), when the flow of information, which is changing rapidly at that, does not leave the possibility and the necessity of "digesting" this information, understanding it, rooting it in the mind, with the result that fragmentarity, superficiality, technocracy, and schematicism are becoming dominant in the culture of information production and consumption? The education as such is challenged as a translation of sociocultural experience in a dialogue between generations, and the scientists have not yet reached a consensus in assessing its transition to the digital mode. Many researchers are of the opinion that the educational system should adapt to the digital era and digital technologies, which the efficiency and the progress of the educational system are associated with (Lapchik \& Fedorova, 2016; Tiukavkin, 2019), while others, noting the advantages of digitalization of education, also point to the risks that come laden with this process: avoidance of fundamentality, the loss of status of Russian education, "drain" of talented youth abroad, lack of personal contacts in the educational process, etc. (Strekalova, 2019).

Of course, it should not be denied that the transition to the digital economy, which is no longer a matter of argument, requires the digital transformation of education (Uvarov et al., 2019), but we must understand that this process is fraught with dangerous risks, one of which is already a topical issue on the agenda - it is the risk to lose the social actor, the actor that creates culture. The educational system in Russia which develops according to the logic of unification, following Western norms and methods, is no longer able to create such an actor, as the educational and professional community itself (Professors and teachers) has found itself in a position of agentless actors, deprived of academic freedoms and rights, and according to Z.T. Toshchenko (2000), the basic democratic principles are not observed in the university environment (Nezavisimaya gazeta, 2020). The educational system, having lost its main actor in the form of the pedagogical community which is ignored in the planning and implementation of objectives aimed at changing the English educational system in the spirit of the digital trends of the modern economy, is unable to prepare a social and cultural actor. "Higher education in Russia runs a fever. At the heart of it is a flawed educational policy that confronts both those who formulate it and those who implement it or will be intended to do it in years to come while working with the students" (Nezavisimaya gazeta, 2020), and the students are immersed in the chaotic world of information, in which the extremely multifaceted process of globalization conveys such values and attitudes that are often false but are determined by fashion or economic situation to the general population. This has an impact on the educational system in the form of practical simplification of the educational process (introduction of the Unified State Examination and online practical trainings), endless standardization, optimization, etc.). The human being itself in the context of the world and its meanings, in the context of society and its meaningfulness, the human being as an actor who creates himself and the world around him, "drops out" of the core of the educational process and therefore does not become a culture-creating actor. In this, we see the dramatic nature of a perfectly logical but highly contradictory historical dynamics within the framework of the information path. In our opinion, it causes the principal risks of the digital transformation of the culture of education, the implications of which threaten further decrease in cultural immunity of Russian society. 


\section{Conclusion}

In this paper, we were aiming at showing the importance of the understanding of the culture of education which transforms under the influence of global processes of informatization and digitalization and determines the current state of cultural immunity of Russian society. The latter is characterized by crisis manifestations which are traceable at all levels of historical and cultural life of Russian society, in which the general cultural background is going down, illiteracy and ignorance are growing, and the values of trust, decency, honor, dignity, accomplishment and educatedness, kindness and sincerity which once were traditional for the Russian nation, are losing their significance, while pragmatic values and behavior models are dominating, and the cult of consumerism and material values prevails (Gorshkov, 2016).

Conclusions and generalizations contained in this paper, are related, first, to the fact that the topical problem of the transformation of the culture of education definitely calls for the substantiation of a multidimensional sociological construct which is reflective of a new information reality in the field of education, its positive effect as well as the risks associated with the distortion of historical memory and a decrease in cultural immunity of society as the ability to resist the invasion of extraneous elements into the cultural fabric of society. Second, important issues for the researcher of this problem include the interpretation of the actualization of historical memory as a means of improving cultural immunity and, accordingly, development of potential of the culture of education. Third, there is a need to analyze historical memory of society not within the restricted limits of revised history, but within the scope of prospects for the integrative potential of the culture of education.

The analysis of available works in the designated research-and-development space, including social philosophical, has shown that the problems that are associated with cultural immunity and the culture of education, have been claimed to be highly relevant and requiring further study. However, first, it is not presented in a cohesive conceptual construct that incorporates the abovementioned problems and categories into a single subject field, and, second, there is no socio-philosophical methodological basis with a conceptual construct and a cognitive research scheme, that allows us to view the topic and the range of problems we have set forward as not only socially relevant in the context of Russian reality, but also scientifically promising. These prospects are associated with the answer to the two grand questions: what risks endanger the cultural immunity of Russian society in the light of the transformation of the culture of education in a digital era and what resources it has to eliminate and prevent them, while rapidly losing the potential of subjectivity in various spheres of life, including in the field of education and culture?

\section{Acknowledgments}

The research was performed within the framework of grant by the President of the Russian Federation for state support of young Russian scientists - Doctors of Sciences (MD - 1493.2020.6) on the topic «The Resource of Historical Memory in the System of Institutional Parameters of Social-Investment Development and Ensuring the Cultural Security of the Region».

\section{References}

Actual problems of social cognition (1982). Moscow: Nauka.

Agapov, Y. (2013). The culture of education and the formation of an educational actor. Gramota, 6(32), 13-17.

Assmann, Y. (2004). Cultural memory: writing, memory of the past and political identity in high rise cultures of the antiquity. Moscow: Languages of Slavonic culture.

Babloyan, N.V. \& Vasilenko, M.A. (2018). Social immunity and the ways of overcoming social inequality. Inzhenernyi Vestnik Dona, $2 . \quad$ URL: ivdon.ru/ru/magazine/archive/n2y2018/4875

Bayanova, A.R., Sizova, Z.M., Chistyakov, A.A., Prokopyev, A.I. \& Vasbieva, D.G. (2019). A philosophical view of organizational culture policy in contemporary universities. European Journal of Science and Theology, 15(3), 121-131.

Boykov, V.E. (2011). Historical memory in modern Russian society: current state and formation problems. Sotsiologiya Vlasti, 5, 44-52.

Flier, A.Y. (2017) Culture theory: Generalization experience. Kultura Kultury, 4. URL: http://cult-cult.ru/the-theory-of-culture-a-new-generalization/

Frolova, N.A., Aleshchanova, I.V. \& Zheltukhina, M.R. (2019). The current state of the German island dialects in the Lower Volga region. SHS Web of Conferences, 69, 00042. 
https://doi.org/10.1051/shsconf/20196900042

Gorshkov, M.K. (2016). Russian society as it is (sociological diagnostics experience): vol. 2. Moscow: Novyi Khronograf.

Halbwachs, M. (2007). Social boundaries of memory. Moscow: Novoe Izdatelstvo Publishing House.

Kara-Murza, S. (2016). Destruction of culture. URL: https://nsportal.ru/blog/kultura/library/2016/10/03/razrushenie-kultury-s-g-kara-murza

Kuts, V. (2013). Cultural immunity as the forefront of the information self-protection of Russian culture and intelligence of Russians. Obshchestvo. Sreda. Razvitie (Terra Humana), 4(29), 159-164.

Kuts, V. (2015). Protective functions of culture. Kultura Kultury, 2. URL: http://cultcult.ru/protective-functions-of-culture/

Kuzmina, G.P. (2010). Organic concept of social development in the works of Russian organic sociologists. Solov'evskie Issledovaniya, 1, 36-51.

Lapchik, M.P. \& Fedorova, G.A. (2016). Innovative approach to pedagogic personnel training in the field of informatization of education. Prepodavatel XXI Vek, 4, 28-41.

Lubskiy, A.V. \& Kovalev, V.V. (2020). From "onlinization" of the higher education system to online education. Gumanitariy Yuga Rossii, 9(2), 33-50.

Nezavisimaya gazeta. (2020). What the never-ending optimization of education brings us to. URL: http://www.ng.ru/stsenarii/2020-01-27/9_7778_education.html?print=Y.

Nora, P. (1999). Les Lieux de Mémoire. St. Petersburg: Publishing House of the St. Petersburg State University.

Romanova, K.S. (2016). Historical memory discourses. Diskurs-Pi Scholarly journal, 3(24-25), 31-36.

Russian society. (2018). Russian society after the Presidential Election in 2018: a request for changes. Information and analytical report. Moscow: Federal Center of Theoretical and Applied Sociology of the Russian Academy of Sciences.

Shabalina, O., Timofeev, G., Davtian, A., Zheltukhina, M. \& Moffat, D. (2019). Investigating regional heritage through the development and playing of AR games. Proceedings of the European Conference on Games-based Learning. 13. "Proceedings of the 13th International Conference on Game Based Learning, ECGBL 2019", 631-638. https://doi.org/10.34190/GBL.19.030

Shapinskaya, E.N. (2019). Education in a digital era: learning or entertainment? Kultura Kultury, 2. URL: http://cult-cult.ru/education-in-the-digital-age-learning-or-entertainment/

Strekalova, N.B. (2019). Risks of adoption of digital technologies in education. News Bulletin of Samara State University. History, pedagogics, philology, 25(2), 84-88.

Tiukavkin, N.M. (2019). Digitalization of educational processes in higher educational establishments. Ekspert: Teoriya i Praktika, 1(1), 35-41.

Toshchenko, Z.T. (2000). Historical consciousness and historical memory. The analysis of the current state. Novaya i Noveyshaya Istoriya, 4, 3-14.

Uvarov, A.Yu., Dvoretskaya, I.V., Zaslavsky, I.M., Karlov, I.A., Mertsalova, T.A., Frumin, I.D. (2019). Constraints and Perspectives of the digital transformation of education. Moscow: Publishing House of the Higher School of Economics.

Varova, N.L. (2012). The culture of education in the modern civilization. Sovremennye Problemy Nauki i Obrazovaniya, 4. URL: http://science-education.ru/ru/article/view?id=6779.

Vodenko, K.V. (2000). Theory and methodology of the research into the role of resource of historical memory in the formation of social investment model of regional development. Gumanitariy Yuga Rossii, 2, 258-267.

Vodenko, K.V., Belasheva, I.V., Zalevskaya, A.A., Polshakova, I.N. \& Tleptserishcheva, S.A. (2019). The State Management of Development of the Professional and Qualification Potential in Russian Higher Education. On The Horizon, 27(3-4), 166-172.

Vodenko, K.V., Borovaya, L.V. \& Yefimov, A.V. (2020). Cultural immunity of Russian society in the light of the transformation of the culture of education. Gumanitariy Yuga Rossii, 4, 36-49. 
Vodenko, K.V., Chernykh, S.S., Ustimenko, D.L., Ustimenko, A.L. (2020). Politics of Memory as a Tool of Civic Culture Formation: The Russian Specifics and Regional Aspects. Journal of History Culture and Art Research, 9(2), 175-183.

Vodenko, K.V., Ponomaryov, P.A., Vergun, T.V., Zritneva, E.I. \& Volkova, L.A. (2018). University as Center Of Regional Social-Economic and Scientific-Innovative Development. Modern Journal of Language Teaching Methods, 8(3), 76-86.

Yevstafiev, D. \& Tsyganova, L. (2020). Transformations of social space as the apprehension of a new world. URL: https://expert.ru/2020/05/6/transformatsii-sotsialnogo-prostranstvakak-predchuvstvie-novogo-mira/

Zhapuev, Z.A. (2013a). Research methodology of the social immunity of Russian society in the context of the institutional transformation and riskogenics. Istoricheskaya $i$ SotsialnoObrazovatelnaya Mysl, 2, 142-146.

Zhapuev, Z.A. (2013b). Social immunity as the subject of sociological research: conceptualization of the idea. Gumanitarnye, Sotsialno-Ekonomicheskie i Obshchestvennye Nauki, 2, 4650.

Zhuk, A.A. (2018). Institutional traps in the field of higher education. Aktualnye Problemy Ekonomiki i Prava, 12(4), 788-799. 